\title{
Preparation of an anti-diethylstilbestrol monoclonal antibody and development of an indirect competitive ELISA to detect diethylstilbestrol in biological samples
}

\author{
LI WeiHua ${ }^{1}$, MENG Meng ${ }^{2}$, HE FangYang ${ }^{3}$, WAN YuPing ${ }^{3}$, XUE HuYin $^{2}$, LIU Wei ${ }^{1}$, \\ YIN WeiWei ${ }^{1}$, XU Jing ${ }^{1}$, FENG CaiWei ${ }^{3}$, WANG ShanLiang ${ }^{3}$, LU Xiao ${ }^{4}$, LIU JinTing ${ }^{1 *}$ \& \\ XI RiMo ${ }^{2 *}$ \\ ${ }^{1}$ School of Chemistry and Chemical Engineering, Shandong University, Jinan 250100, China; \\ ${ }^{2}$ College of Pharmacy and Tianjin key Laboratory of Molecular Drug Research, Nankai University, Tianjin 300071, China; \\ ${ }^{3}$ Beijing Wanger Biotechnology Co., Ltd., Beijing 102206, China; \\ ${ }^{4}$ Central Laboratory of Shandong Academy of Agricultural Sciences, Jinan 250100, China
}

Received April 22, 2010; accepted August 5, 2010

\begin{abstract}
Based on the preparation of an anti-diethylstilbestrol (DES) monoclonal antibody, a simple and convenient indirect competitive enzyme-linked immunosorbent assay (ELISA) method for DES detection has been developed. The monoclonal antibody demonstrated high sensitivity to DES with an $\mathrm{IC}_{50}$ value of $275 \mathrm{pg} \mathrm{mL}^{-1}$ and detection limit (LOD) of $90 \mathrm{pg} \mathrm{mL} \mathrm{m}^{-1}$. The specificity of the assay was studied by measuring cross-reactivity of the antibody with structurally related compounds of ethinyl estradiol $(<7 \%)$, estrone $(<0.1 \%)$, estriol $(<0.1 \%)$, and diethylstilbestrol benzoate $(<0.1 \%)$. Chicken, fish, shrimp, urine and bile spiked with different concentration of DES were detected by the developed method, and the recovery rates were greater than $79.5 \%$. Intra- and inter-assay variations were about $6 \%$. This method exhibited high stability with a coefficient of variation less than $10 \%$ in buffer and in real samples. The LODs in fish/shrimp, liver, feed and urine spiked with DES were 600, 600, 4800 and $600 \mathrm{pg} \mathrm{mL}^{-1}$, respectively. These results confirmed that the antibody to DES was successfully produced and could be used to establish ELISA methods for DES detection in food producing animals.
\end{abstract}

diethylstilbestrol, ELISA, monoclonal antibody, drug residue

Citation: $\quad \mathrm{Li} \mathrm{W} \mathrm{H}$, Meng M, He F Y, et al. Preparation of an anti-diethylstilbestrol monoclonal antibody and development of an indirect competitive ELISA to detect diethylstilbestrol in biological samples. Chinese Sci Bull, 2011, 56: 749-754, doi: 10.1007/s11434-010-4322-x

Diethylstilbestrol (DES; Figure 1) is an orally active synthetic non-steroid estrogen. Since the 1960s, DES has been used as a growth-promoting agent in livestock [1,2]. Later, DES was found to cause cancer and its use was "phased out in the 1970s" by the FAO/WHO. In 1971, DES was reported to be a teratogen when given to pregnant women and has been associated with a rare vaginal cancer in female offspring [3]. On February 5, 1975, the US Food and Drug Administration (FDA) ordered 25 and $100 \mathrm{mg}$ tablets of DES withdrawn; however, it was still illegally used in the livestock industry.

*Corresponding authors (email: xirimo2000@yahoo.com; jintliu@sdu.edu.cn)
More than 30 years of researches have confirmed that DES is a teratogen, which can cause malformations of an embryo or fetus. Prenatal exposure to DES is associated with an increased incidence of fibroids of adulthood [4,5]. Therefore, the Ministry of Agriculture of the People's Republic of China issued a banned list (Announcement No. 235; http://www. agri.gov.cn/ zcfg/bmgz/ t20060123_540865.htm, accessed on October 24,2002 ) of veterinary drugs and announced that the use of DES in food and animal feed was prohibited. The European Union (EU) requires that residual levels of DES in edible animal food should not exceed $2 \mathrm{ng} \mathrm{mL}^{-1}$ [6]. Consequently, a rapid screening method with high sensitivity and 


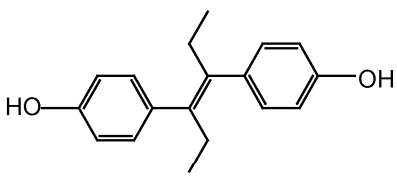

Diethylstilbestrol (DES)

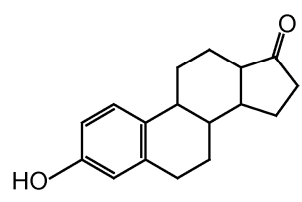

Estrone

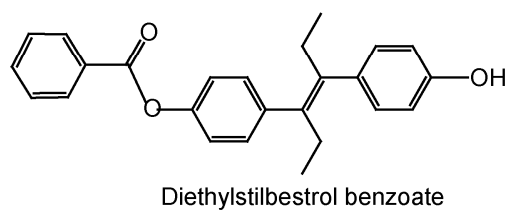

Figure 1 Diethylstilbestrol (DES) and related compounds analyzed in this study.

excellent stability is urgently required.

Determination of DES levels is mainly carried out by high-performance liquid chromatography detection methods $[7,8]$, gas chromatography-mass spectrometry [9], colorimetric assay [10] and chemiluminescence [11]. The chromatography method demonstrated high sensitivity, however the instruments are expensive and sample pretreatment is complicated and time-consuming. Therefore, it is not suitable for rapid screening tests. The enzyme-linked immunosorbent assay (ELISA) technique is sensitive, specific and cost effective, and has been used diagnostically in recent years. Furthermore, ELISA methods have also been used for detection of various drug residues in the real system, such as in food and biological samples [12,13].

The sensitivity of an ELISA test is significantly influenced by the antibody against the compound being detected. Wang et al. [14,15] produced two kinds of similar polyclonal antibodies against DES with $\mathrm{IC}_{50}$ of 1.02 and $1.89 \mu \mathrm{g} \mathrm{L} \mathrm{L}^{-1}$, respectively. $\mathrm{Xu}$ et al. $[16,17]$ also prepared a polyclonal antibody against DES with an average $\mathrm{IC}_{50}$ value of $2.4 \mathrm{ng}$ $\mathrm{mL}^{-1}$, a calibration range of $0.2-30.5 \mathrm{ng} \mathrm{mL}^{-1}$, and a detection limit of $0.07 \mathrm{ng} \mathrm{mL}^{-1}$. Compared with the polyclonal antibody, the application of a monoclonal antibody (MAb) was advantageous in terms of purity, sensitivity and specificity. Up to now, there is no research reported on the preparation of monoclonal antibody for DES. The aim of our study is to develop an ELISA method based on the monoclonal antibody toward DES, and detect DES spiked in the animal (chicken, shrimp) tissue, urine and bile.

\section{Materials and methods}

(i) Chemicals. Bovine serum albumin (BSA), ovalbumin
(OVA) and goat anti-mouse IgG-horseradish peroxidase (HRP) conjugated antibody were provided by Beijing Wanger Biotechnology (Beijing, China). 3,3',5,5'-tetramethylbenzidine (TMB) was purchased from Xinjingke Biotechnology (Beijing, China). N-hexane, hydrochloric acid, dimethylsulfoxide (DMSO), sulfuric acid, sodium hydroxide, acetonitrile, hydrogen peroxide $\left(30 \% \mathrm{H}_{2} \mathrm{O}_{2}\right)$ and other reagents were provided by Guangmang Chemical Company (Jinan, China). Chicken samples and pig liver samples were purchased from a supermarket in Jinan (China).

(ii) Instruments and consumables. ELISA was performed in polystyrene 96-well microtitre plates (Bio Basic Inc., Markham, Ontario, Canada) and spectrophotometrically read with a Model 680 microplate reader (Bio-Rad, Hercules, CA, USA). Centrifugation was carried out in a Biofuge Stratos refrigerated centrifuge (Heraeus, Germany). The dialysis bags ( $\mathrm{MWCO}=8000-14000$ ) were from Aibo Economic \& Trade (Jinan, China).

(iii) Buffers. Ultrapure deionized water was used for preparation of all buffers and reagents for the immunoassays, unless otherwise indicated. Phosphate-buffered saline (PBS; $\mathrm{pH}$ 7.4) consisted of $138 \mathrm{mmol} \mathrm{L}^{-1} \mathrm{NaCl}, 1.5 \mathrm{mmol} \mathrm{L}^{-1}$ $\mathrm{KH}_{2} \mathrm{PO}_{4}, 7 \mathrm{mmol} \mathrm{L}^{-1} \mathrm{Na}_{2} \mathrm{HPO}_{4}$ and $2.7 \mathrm{mmol} \mathrm{L}^{-1} \mathrm{KCl}$. The wash buffer (PBST) was PBS supplemented with $0.05 \%(\mathrm{v} / \mathrm{v})$ Tween 20. The $0.05 \mathrm{~mol} \mathrm{~L}^{-1}$ carbonate coating buffer contained $15 \mathrm{mmol} \mathrm{L}^{-1} \mathrm{Na}_{2} \mathrm{CO}_{3}$ and $35 \mathrm{mmol} \mathrm{L}^{-1} \mathrm{NaHCO}_{3}(\mathrm{pH}$ 9.6). The blocking buffer was a solution of PBS mixed with $1 \%$ OVA and $0.05 \%(\mathrm{v} / \mathrm{v})$ Tween 20 . The substrate buffer was $0.1 \mathrm{~mol} \mathrm{~L}^{-1}$ sodium acetate/citrate buffer ( $\left.\mathrm{pH} 5.0\right)$. An 80 $\mathrm{mL}$ volume of acetonitrile was added to $20 \mathrm{~mL}$ of $0.1 \mathrm{~mol} \mathrm{~L}^{-1}$ $\mathrm{HCl}$ and used as an extraction solution in the preparation of the biological samples. To prepare the substrate solution, 10 $\mathrm{mg}$ of TMB was dissolved in $5 \mathrm{~mL}$ of DMSO (substrate solution A) and $5 \mu \mathrm{L}$ of $30 \%(w / w) \mathrm{H}_{2} \mathrm{O}_{2}$ added to $15 \mathrm{~mL}$ of citrate buffer (substrate solution $\mathrm{B}$ ) was mixed together. A 2 mol L-1 $\mathrm{H}_{2} \mathrm{SO}_{4}$ solution was used to stop the reaction.

(iv) Preparation of the DES hapten. The hapten of DES was synthesized via sodium chloroacetate according to the literature [15] with some modifications (Figure 2). DES $(537 \mathrm{mg}$ ) was dissolved in $20 \mathrm{~mL}$ of dioxane, then $4 \mathrm{~mL}$ of sodium chloroacetate solution was slowly added, and $2 \mathrm{~mL}$ of sodium carbonate solution was added to the mixture above, then the solution was heated to $70^{\circ} \mathrm{C}$ and stirred overnight. The mixture was filtered and the filtrate was distilled by rotary evaporators. The residue was dissolved in chloroform and then petroleum ether was added. The precipitated flocculent was collected to obtain the DES hapten.

(v) Preparation of the coating antigen and immunogen. The conjugates of DES coupled with OVA and BSA were used as coating antigen and immunogen, respectively. As shown in Figure 3, the preparation of OVA-DES involved $1.0 \mathrm{~mL}$ of hapten as obtained above, $20 \mathrm{mg}$ of dicyclohexylcarbodiimide (DCC) and $12.5 \mathrm{mg}$ of $N$-hydroxysuccinimide (NHS) dissolved in $0.5 \mathrm{~mL}$ of dimethylformamide 

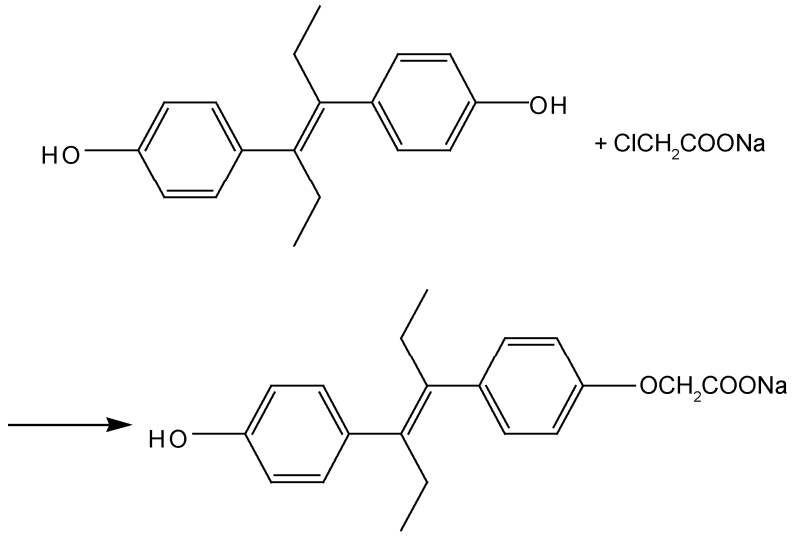

Figure 2 Synthesis of the DES hapten.
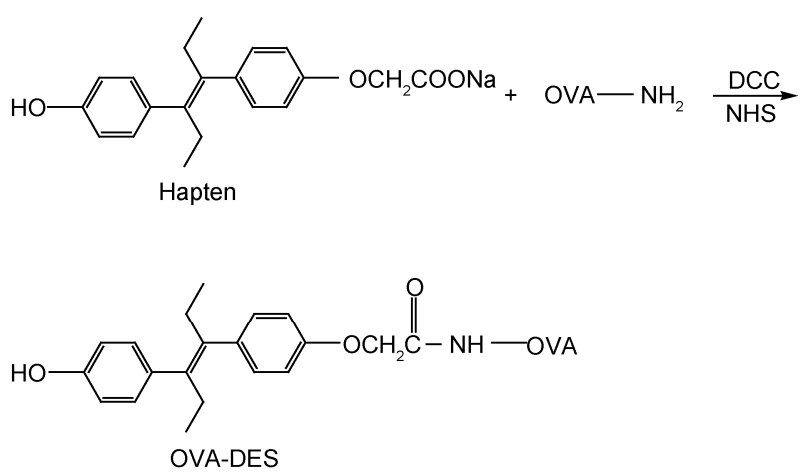

Figure 3 Synthesis of coating antigen OVA-DES.

and mixed for $24 \mathrm{~h}$ at room temperature, yielding solution I. OVA $(50 \mathrm{mg})$ was dissolved in $3.5 \mathrm{~mL}$ of PBS $(0.01 \mathrm{~mol}$ $\mathrm{L}^{-1}, \mathrm{pH}$ 7.2) to obtain solution II. Solution I was added to solution II slowly and the mixture obtained was stirred at room temperature for $3 \mathrm{~h}$ to remove small impurities. The mixture was centrifuged at $10000 \times g$ for $30 \mathrm{~min}$ and the supernatant was collected to obtain OVA-DES, which was stored at $-20^{\circ} \mathrm{C}$ for future use. The BSA-DES immunogen was synthesized in the same way.

(vi) Production of anti-DES MAbs. BALB/c mice were immunized by an intraperitoneal injection of $80-100 \mu \mathrm{g}$ of BSA-DES with complete Freund's adjuvant. Three booster injections were performed using the same amount of BSA-DES with incomplete Freund's adjuvant at an interval of two weeks. Antiserum was collected and their titers were evaluated by an indirect competitive ELISA method. After the immune response was confirmed, the splenocytes from immunized mice were fused with mouse myeloma cells Sp2/0 (7:1, cell ratio) using the polyethylene glycol (PEG) method [18] and cells were suspended in hypoxanthineaminopterin-thymidine medium. The hybridoma cells were cultured in medium ( $\mathrm{pH} 7.4$ ) containing $0.2 \% \mathrm{NaHCO}_{3}$ and RPMI1640 with the addition of $20 \%$ newborn calf serum at $37^{\circ} \mathrm{C}$ to obtain MAbs for DES. The cells were screened by an ELISA assay and cloned by a limiting dilution method.
The purification was performed according to the acid-ammonium sulfate method, and the purified MAbs obtained were stored at $-20^{\circ} \mathrm{C}$.

(vii) Characteristics of antibody as assessed by an indirect competitive ELISA method. The titer of the antibody was tested by an indirect competitive ELISA method [13]. The procedure was carried out as described below. The microplates were coated with the coating antigen, OVA-DES, at dilutions of 1/500,1/1000,1/2000, 1/4000, 1/8000, $1 / 16000,1 / 32000$ and $1 / 64000$, and incubated at $37^{\circ} \mathrm{C}$ for $2 \mathrm{~h}$. Plates were washed three times, blocked with $250 \mu \mathrm{L} /$ well of blocking buffer, incubated at $4{ }^{\circ} \mathrm{C}$ overnight. Plates were washed three times again, then the antisera at different dilutions were added and incubated for $1 \mathrm{~h}$ at room temperature. After washing, goat anti-mouse IgG-HRP (1:1000, $100 \mu \mathrm{L} /$ well) was added and incubated for $30 \mathrm{~min}$ at room temperature. Plates were washed three times and TMB substrate solution was added. After that, the plates were incubated for $15 \mathrm{~min}$ at room temperature. The color development was inhibited by adding stop solution $(100 \mu \mathrm{L} /$ well $)$ and the absorbance at $450 \mathrm{~nm}$ was measured. Absorbance values were corrected by a blank reading. The antibody titer was defined as the reciprocal of the dilution that resulted in an absorbance value twice that of the blank value.

The sensitivity of antibody was determined by the same method as described above, except that different concentrations $\left(0,50,150,450,1350\right.$ and $\left.4050 \mathrm{pg} \mathrm{mL}^{-1}\right)$ of DES (50 $\mu \mathrm{L} /$ well) were mixed with antibody $(50 \mu \mathrm{L} /$ well) that was added to the plates coated with the coating antigen at the optimal concentration. The absorbance values at $450 \mathrm{~nm}$ were used to calculate the percent inhibition using the following equation: inhibition $\%=B / B_{0} \times 100$, where $B$ was the absorbance value for the well containing the competitor and $B_{0}$ was the absorbance for the well without competitor.

The specificity of the antibody was evaluated by measuring inhibition curves using four functionally or structurally similar analogues as competitors, including ethinyl estradiol, estrone, estriol and diethylstilbestrol benzoate (Figure 1). The specificity was expressed as the cross-reactivity of each compound, which was determined by comparing the DES concentration required to produce a $B / B_{0}$ that was equal to $50 \%$ to that of the tested analyte.

(viii) Biological samples used for matrix effect determination. Animal (chicken and shrimp) tissue samples were pretreated by homogenizing for 10-15 $\mathrm{min}$, then $2 \mathrm{~g}$ of the homogenized tissue was placed in a polythene tube and 6 $\mathrm{mL}$ of extraction solution (acetonitrile/acetone $=4: 1, \mathrm{v} / \mathrm{v}$ ) was added. The mixture was shaken vigorously for $10 \mathrm{~min}$ at $15^{\circ} \mathrm{C}$ and centrifuged for $5 \mathrm{~min}$ at $700 \times g$. A $3 \mathrm{~mL}$ volume of the supernatant was dried at $55^{\circ} \mathrm{C}$. After that, $0.5 \mathrm{~mL}$ of chloroform and $2 \mathrm{~mL}$ of $2 \mathrm{~mol} \mathrm{~L}^{-1} \mathrm{NaOH}$ was added, stirred and shaken for $30 \mathrm{~s}$, then centrifuged at $3000 \times \mathrm{g}$ for $5 \mathrm{~min}$. Approximately $1 \mathrm{~mL}$ of the supernatant was mixed with 200 $\mu \mathrm{L}$ of $6 \mathrm{~mol} \mathrm{~L}^{-1} \mathrm{H}_{3} \mathrm{PO}_{4}$ and $3 \mathrm{~mL}$ of acetonitrile. This mix- 
ture was centrifuged at $3000 \times g$ for $10 \mathrm{~min}$. After the organic phase was dried under nitrogen, the residue was mixed with $1 \mathrm{~mL}$ of reconstitution solution and used for analysis.

For the treatment of urine and bile, $2 \mathrm{~mL}$ of urine (or bile) and glucuronidase was transferred to a polythene tube. The mixture was centrifuged at $3000 \mathrm{r} / \mathrm{min}$ for 10 min at room temperature and $1 \mathrm{~mL}$ of the supernatant was mixed with $5 \mathrm{~mL}$ of chloroform, then centrifuged twice at room temperature for $10 \mathrm{~min}$ at $3000 \mathrm{r} / \mathrm{min}$. After the organic phase was dried under nitrogen, the residue was mixed with $1 \mathrm{~mL}$ of reconstitution solution and used for analysis.

(ix) Validation of the indirect ELISA method. To detect the precision of the ELISA developed, $0.45 \mu \mathrm{g} \mathrm{L}^{-1}$ DES solution was detected repeatedly. The intra-assay variation was measured by analysis of a $0.45 \mu \mathrm{g} \mathrm{L}^{-1}$ DES standard solution six times on a single day. The inter-assay variation was measured by analysis of a $0.45 \mu \mathrm{g} \mathrm{L}^{-1}$ DES standard solution six times over three different days.

To detect the matrix effect on the repeatability and accuracy of the test, 1.0 and $2.5 \mu \mathrm{g} \mathrm{kg}^{-1} \mathrm{~L}^{-1}$ DES was added to animal tissues, urine and bile, then analyzed. Samples containing spiked levels were detected five times to ascertain the accuracy of the method. The coefficient of variation (CV) was obtained by the formula: $\mathrm{CV} \%=$ standard deviation $\times 100$ /average.

\section{Results and discussion}

\subsection{Production of immunogen}

As a small molecule, DES itself was not immunogenic. A functional group (carboxyl, amino or hydroxyl) in the hapten for coupling the carrier proteins is required for establishing an ELISA method. The structure of DES (Figure 1) showed that the hydroxyl group is an important functional group for hapten synthesis, and likely to be a structural feature for this molecule in immunization.

Monoetherification was carried out during hapten synthesis for preserving a characteristic group and introducing a new functional group. For production of an antibody capable of recognizing an analyte, the haptens should be designed to expose its characteristic group to the largest extent. Spacer arms with different lengths connecting the target analyte to the carrier protein affect antibody formation. The hapten was synthesized by replacing the $\mathrm{H}$ residue in the phenolic hydroxyl of DES with a carboxyl group at the end. Haptens were then coupled with the carrier proteins to induce an immune response. The key factor for generating a successful ELISA assay is to produce a sensitive and highly selective antibody to the tested drug; therefore, we mainly focused on the titer and competitive characteristics of the antibody obtained. Consequently, the structure of the hapten and its coupling ratio with a carrier protein was not investigated.

\subsection{Antibody evaluation}

The titer of the serum from each animal was determined by measuring the binding of serial dilutions of antisera with the coating antigen. The titer of MAbs developed was more than 100000. The optimized concentration of coating and dilution of MAbs used was $1 \mu \mathrm{gL}^{-1}$ and $1: 4000$, respectively. The representative inhibition and standard curves are shown in Figures 4 and 5, respectively. As can be seen from the Figure 4, the sensitivity of the antibody was satisfactory with an $\mathrm{IC}_{50}$ value of $275 \mathrm{pg} \mathrm{mL}^{-1}$ and a limit of detection (LOD; $\mathrm{IC}_{10}$ ) of $90 \mathrm{pg} \mathrm{mL}^{-1}$ in buffer, significantly lower than the acceptable level set out by the EU of $2.0 \mathrm{ng} \mathrm{mL}^{-1}$. Comparing the published ELISA methods $\left(\mathrm{IC}_{50}=1.02 \mu \mathrm{g}\right.$ $\mathrm{L}^{-1}$ [14]; $\mathrm{IC}_{50}=1.89 \mu \mathrm{g} \mathrm{L}^{-1}$ and $\mathrm{LOD}=0.08 \mu \mathrm{g} \mathrm{L}^{-1}$ [15]), the antibody obtained by us demonstrated remarkably higher sensitivity. DES was able to compete with the coating antigen to interact with the antibody in the range of $50-1350 \mathrm{pg} \mathrm{mL}^{-1}$, and in this range the absorbance value exhibited a good linear relationship with a logarithmic DES concentration $\left(R^{2}=0.993\right.$; Figure 5$)$. Based on the preparation of the polyclonal antibody against DES, Xu et al. $[16,17]$ established a direct ELISA method for DES detection. A DES-HRP conjugate was required to perform the direct ELISA assay. To avoid synthesis problems in the process of conjugation, commercially available goat antimouse IgG-HRP was used to develop an indirect ELISA method in our study. Results show that the assay generated in our research was also more sensitive than the direct ELISA assay $\left(\mathrm{IC}_{50}=2.4 \mathrm{ng} \mathrm{mL}^{-1}\right)$.

The specificity of the antibody was detected with three functionally and one structurally related compounds. As

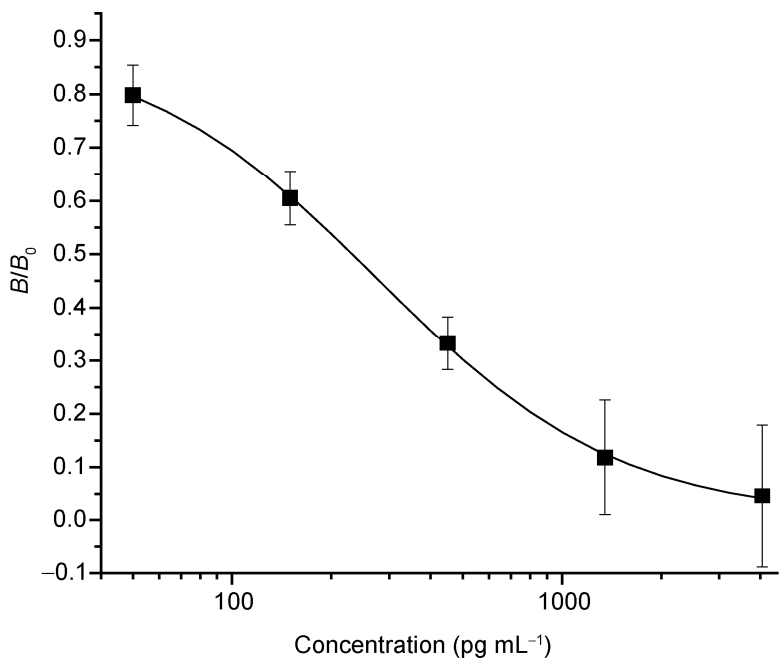

Figure 4 Representative inhibition curve of the anti-DES antibody using DES as the competitor and DES-OVA as the coating antigen in PBS. Each point represents the average of five replicates. 


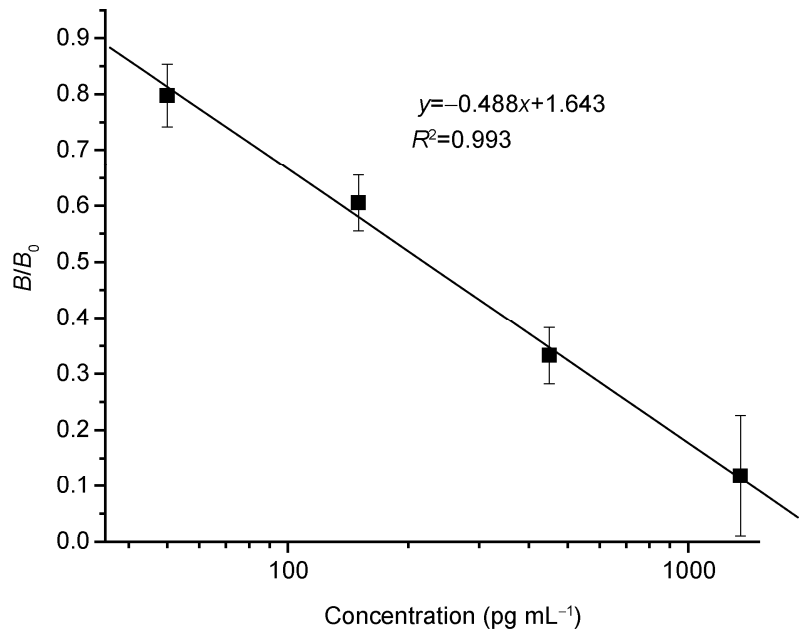

Figure 5 Linear standard curve of the anti-DES monoclonal antibody binding with the coating antigen. Each point represents the average of five replicates.

shown in Table 1, ethinyl estradiol, estrone, estriol and diethylstilbestrol benzoate displayed low cross-reactivity with $<7 \%,<0.1 \%$ and $<0.1 \%$, respectively, indicating the excellent selectivity of the antibody obtained by us. The high specificity also confirmed our speculation that phenolic hydroxyl is an important structural feature in inducing an immune response against DES.

\subsection{Repeatability of the ELISA method}

A standard DES solution $\left(0.45 \mu \mathrm{g} \mathrm{L}^{-1}\right)$ was measured six times on a single day to determine intra-assay variation. This standard solution was assayed over three different days to calculate inter-assay variation. As shown in Table 2, the coefficient of variation was in the range 3.6\%-9.4\%, intra-assay variation was $5.6 \%-6.2 \%$, and inter-assay variation was less than $6 \%$. These results demonstrated that the developed ELISA was stable and credible for determining the concentration of DES.

\subsection{Matrix effects on the ELISA method}

Animal tissue, urine and bile supplemented with 1.0 or 2.5 ug $\mathrm{kg}^{-1} \mathrm{~L}^{-1}$ DES were analyzed by the ELISA method. Each

Table 1 Percentage cross-reactivity of the DES analog ${ }^{\text {a) }}$

\begin{tabular}{cc}
\hline Analogue & Cross-reactivity (\%) \\
\hline DES & $100 \%$ \\
Ethinyl estradiol & $<7 \%$ \\
Estrone & $<0.1$ \\
Estriol & $<0.1$ \\
Diethylstilbestrol benzoate & $<0.1$ \\
\hline
\end{tabular}

a) Cross-reactivity was determined by comparing the concentration of the analyte required to produce a $B / B_{0}$ equal to $50 \%$. Results were expressed as a percentage relative to the value for DES.
Table 2 Coefficient of variation (CV) for detection of the $0.45 \mu \mathrm{g} \mathrm{L}$ DES standard solution ${ }^{\text {a) }}$

\begin{tabular}{cccc}
\hline \multirow{2}{*}{ Detection number } & \multicolumn{3}{c}{ CV $(\%)$} \\
\cline { 2 - 4 } & Day 1 & Day 2 & Day 3 \\
\hline 1 & 5.2 & 3.9 & 5.4 \\
2 & 4.3 & 6.4 & 4.9 \\
3 & 4.8 & 5.8 & 6.2 \\
4 & 6.1 & 7.6 & 5.8 \\
5 & 5.6 & 9.4 & 6.3 \\
6 & 4.2 & 4.5 & 7.4 \\
Intra-assay variation & 5.0 & 6.3 & 6.0 \\
Inter-assay variation & & 5.8 & \\
\hline
\end{tabular}

a) Intra-assay variation was determined by measuring 10 replicates on a single day. Inter-assay variation was determined by measuring 10 replicates over three different days.

sample was analyzed five times to verify recovery, accuracy and stability of the method in a real system. As shown in Table 3, the coefficient of variation was in the range of $2.9 \%-6.3 \%$ for tissue samples, $5.0 \%-6.3 \%$ for urine samples, and $4.6 \%-8.5 \%$ for bile. The CV\% was less than $10 \%$ for all samples, showing the acceptable reproducibility of the assay. The results also demonstrated that the recovery rates were greater than $79 \%$ for all samples (Table 3), demonstrating accuracy of the ELISA in measuring DES in samples. The recovery for animal tissue samples was mildly higher than that for urine and bile.

The matrix effect on the sensitivity of the test was also evaluated. The real systems (fish/shrimp, liver, feed and urine) spiked with different dilutions of DES were analyzed and the results are given in Table 4. The limit of detection for analyzing DES by the method in fish/shrimp, liver and urine was $0.6 \mu \mathrm{g} \mathrm{L}^{-1}$, less than the acceptable level of $2 \mathrm{ng}$ $\mathrm{mL}^{-1}$, showing that the method was suitable for a screening analysis of DES in these matrices. However, the sensitivity of the test was extremely influenced by the feed (LOD $=48$ $\mu \mathrm{g} \mathrm{L}^{-1}$ ). Therefore, the method is not fit to be used in DES detection in feed. Also, the recovery and repeatability tests of the method were not determined in the feed samples.

\section{Conclusions}

In our research, the immunogen was conjugated via the DCC method and a MAb against DES was obtained from immunized mice. The MAb demonstrated high sensitivity and specificity to DES with an $\mathrm{IC}_{50}$ of $275 \mathrm{pg} \mathrm{mL}^{-1}$ and LOD of $90 \mathrm{pg} \mathrm{mL}^{-1}$ in buffer. The functionally and structurally related compounds exhibited lower levels of crossreactivity. The ELISA developed was used to detect DES in animal tissue, urine and bile, and the recovery rate was $79.8 \%-85.6 \%$. The coefficients of variation of DES were both less than $10 \%$ in buffer and real systems. The LOD was $0.6 \mu \mathrm{g} \mathrm{L}^{-1}$ in fish/shrimp, liver and urine and $48 \mu \mathrm{g} \mathrm{\textrm {L } ^ { - 1 }}$ 
Table 3 Detection of DES in animal tissue and urine spiked with DES ${ }^{\text {a) }}$

\begin{tabular}{|c|c|c|c|c|c|c|c|c|}
\hline Sample & DES added & \multicolumn{5}{|c|}{ Measured concentration $\left(\mu \mathrm{g} \mathrm{kg}^{-1} / \mu \mathrm{g} \mathrm{L}^{-1}\right)$} & Recovery $(\%)$ & $\mathrm{CV}(\%)$ \\
\hline \multirow{2}{*}{$\begin{array}{l}\text { Animal } \\
\text { tissue }\end{array}$} & $2.5 \mu \mathrm{g} \mathrm{kg}^{-1}$ & 2.0 & 2.3 & 2.3 & 2.1 & 2.0 & 85.6 & 6.3 \\
\hline & $1.0 \mu \mathrm{g} \mathrm{kg}^{-1}$ & 0.82 & 0.78 & 0.83 & 0.84 & 0.79 & 81.2 & 2.9 \\
\hline \multirow{2}{*}{ Urine } & $2.5 \mu \mathrm{g} \mathrm{L}^{-1}$ & 2.1 & 2.0 & 1.9 & 2.0 & 2.2 & 81.6 & 5.0 \\
\hline & $1.0 \mu \mathrm{g} \mathrm{L}^{-1}$ & 0.77 & 0.82 & 0.73 & 0.88 & 0.79 & 79.8 & 6.3 \\
\hline \multirow{2}{*}{ Bile } & $2.5 \mu \mathrm{g} \mathrm{L}^{-1}$ & 2.3 & 2.0 & 1.8 & 2.2 & 2.0 & 82.4 & 8.5 \\
\hline & $1.0 \mu \mathrm{g} \mathrm{L}^{-1}$ & 0.85 & 0.83 & 0.83 & 0.76 & 0.77 & 80.8 & 4.6 \\
\hline
\end{tabular}

a) $\mathrm{CV}$, coefficient of variation.

Table 4 Limit of dentation (LOD) for DES in biological samples with the developed ELISA method

\begin{tabular}{cc}
\hline Sample & LOD $\left(\mu \mathrm{g} \mathrm{L}^{-1}\right)$ \\
\hline Fish/shrimp & 0.6 \\
Liver & 0.6 \\
Feed & 48 \\
Urine & 0.6 \\
\hline
\end{tabular}

in feed. In summary, an antibody against DES was obtained and could be used to establish an ELISA method to detect DES in most food-producing animals.

This work was supported by the Shandong Natural Science Foundation (Y2008B31), the National High-Tech Research and Development Program of China (07AA10Z435, 2007AA06A407), the National Natural Science Foundation of China (20675048), and the Fundamental Research Funds for the Central Universities (65011121).

1 Preston R, Burroughs W. Stilbestrol responses in lambs fed rations differing in calorie to protein ratios. J Anim Sci, 1958, 17: 140-151

2 Baker D, Jordan C, Waitt W, Gouwens D. Effect of a combination of diethylstilbestrol and methyltestosterone, sex and dietary protein level on performance and carcass characteristics of finishing swine. J Anim Sci, 1967, 26: 1059-1066

3 Paup D, Coniglio L, Clemens L. Hormonal determinants in the development of masculine and feminine behavior in the female hamster. Behav Biol, 1974, 10: 353-363

4 Vorherr H, Messer R. Teratogenesis and carcinogenesis in rat offspring after transplacental and transmammary exposure to diethylstilbestrol. Biochem Pharmacol, 1979, 28: 1865-1877

5 Haaf H, Metzler M. Covalent binding of diethylstilbestrol to microsomal protein in vitro correlates with the organotropism of its carcinogenicity. Carcinogenesis, 1985, 6: 659-660

6 Commission Staff Working Paper on the Implementation of National Residue Monitoring Plans in the Member States in 2006 (Council Directive 96/23/EC). Commission of the European Communities. 2006: 149
7 Williams A T, Winfield S A, Belloli R C. Rapid, specific method for diethylstilbestrol analysis using an in-line photochemicals reactor with high-performance liquid chromatography and fluorescence detection. J Chromatogr A, 1982, 235: 461-470

8 Reuvers T, Perogordo E. Rapid screening method for the determination of diethylstilbestrol in edible animal tissue by column liquid chromatography with electrochemical detection. J Chromatogr Biomed Appl, 1991, 564: 477-484

9 Bagnati R, Castelli M G. Analysis of diethylstilbestrol, dienestrol and hexestrol in biological samples by immunoaffinity extraction and gas chromatography-negative-ion chemical ionization mass spectrometry. J Chromatogr B, 1990, 527: 267-278

10 Duerr J D, Pappas B A. A colorimetric assay for the determination of diethylstilbestrol. J Am Phar Asso, 2006, 48: 13-15

11 Zhang Q L, Li J, Ma T T. Chemiluminescence screening assay for diethylstilbestrol in meat. Food Chem, 2008, 111: 498-502

12 Zhao C B, Liu W, Ling H L, et al. Preparation of anti-gatifloxacin antibody and development of an indirect competitive enzyme-linked immunosorbent assay for the detection of gatifloxacin residue in milk. J Agric Food Chem, 2007, 55: 6879-6884

13 Zhang Y L, Lu S X, Liu W. Preparation of anti-tetracycline antibodies and development of an indirect heterologous competitive enzyme-linked immunosorbent assay to detect residues of tetracycline in milk. J Agric Food Chem, 2007, 55: 211-218

14 Wang W J, Ling Y. Development of an indirect competitive ELISA based on polyclonal antibody for the detection of diethylstilbestrol in water samples. Chin J Chem, 2007, 25: 1145-1150

15 Wang B, Peng C F. Synthesis and analysis of complete antigen of diethylstilbestrol. J Chem Ind Eng (China), 2007, 58: 1523-1528

$16 \mathrm{Xu} \mathrm{C} \mathrm{L,} \mathrm{Chu} \mathrm{X} \mathrm{G,} \mathrm{Peng} \mathrm{C} \mathrm{F,} \mathrm{et} \mathrm{al.} \mathrm{Comparison} \mathrm{of} \mathrm{enzyme-linked}$ immunosorbent assay with liquid chromatography-tandem mass spectrometry for the determination of diethylstilbesterol residues in chicken and liver tissues. Biomed Chromatogr, 2006, 20: 1056-1064

17 Xu C L, Peng C F, Liu L Q, et al. Determination of hexoestrol residues in animal tissues based on enzyme-linked immunosorbent assay and comparison with liquid chromatography-tandem mass spectrometry. J Pharm Biomed Anal, 2006, 41: 1029-1036

18 Liu W, Li W H, Yin W W, et al. Preparation of a monoclonal antibody and development of an indirect competitive ELISA for the detection of chlorpromazine residue in chicken and swine liver. J Sci Food Agric, 2010, 90: 1789-1795

Open Access This article is distributed under the terms of the Creative Commons Attribution License which permits any use, distribution, and reproduction in any medium, provided the original author(s) and source are credited. 